\title{
Miraculous effects of negative ions on urogenital infections
}

\begin{abstract}
Urogenital Infections are frequent and some of them can be transmitted sexually. The symptoms can be the same but caused by different bacteria and virus, so the treatment should be adapted according the laboratory results. Some infections can be resistant to all antibiotics witnessing low immunity and inappropriate previous treatment. The infections can be prevented by healthy hygiene, by Negative Ions (Anion) from products and from the nature, boosting the immunity by alkalinizing the body. In alkaline the bacteria, virus cannot multiply. High concentrations of Negative Ions are in the clean Nature, the God blessing Gift, which we should preserve for our health and future generation. Allah says in the Quran, Surah Al Israa 17-82: “And We send down of the Qur'an that which is healing and mercy for the believers).
\end{abstract}

Keywords: Quran, Nature, Negative Ions (Anion), Gynecological Infections
Volume 9 Issue I - 2018

\section{Mira Bajirova}

Associate Professor, Consultant Ob-Gyn, Healthcare Medical Center, UAE

Correspondence: Dr. Mira Bajirova, Associate Professor, Consultant Ob-Gyn, IVF (Paris), Healthcare Medical Center, Dubai, UAE, Email docfromparis@gmail.com

Received: October 22, 2017 | Published: January 16, 2018

\section{Introduction}

The Urogenital infections present similar symptoms like vaginal itching, burning, discharge, urinary tract symptoms, pelvic and back discomfort but caused by different bacteria, virus, and the treatment should be based on laboratory tests. Prescribing blindly the treatment without evidence based laboratory proven bacteria/virus is a big mistake.

\section{Vaginal candidiasis}

The most frequent vaginal infection is a Vaginal Candidiasis. which can be caused by

a. Sanitary napkins. There is no research that unequivocally declares these feminine hygiene products are safe, and independent studies by women's health organizations have found chemicals from petrol industry, pesticide. Bactericide, dioxin, carcinogens, and reproductive toxins in tampons and pads. ${ }^{2}$

b. Increased humidity in genital area : synthetic underwear, jeans, leather, wet bikini

c. Antibiotics increasing the vaginal acidity

d. Hormonal contraception, IUD

e. Low immunity - pregnancy, diabetes, HIV, cancer, other diseases

f. Sexual intercourse

g. Low hygiene

There are many types of Candida and some of them cannot be detected by basic technique (wet and culture) and can be detected by PCR like Candida Glabrata and the treatment is completely different.

\section{Ureaplasma and mycoplasma}

Ureaplasma and Mycoplasma became very frequent infection in women and men.,4 Many clinicians are unfamiliar with Mycoplasma and Ureaplasma species as etiologic agents or skeptical or do not screen for these infections or manage wrongly informing patients that they are normal microorganisms in human body. This unfamiliarity is further complicated by a lack of facilities to diagnose Ureaplasma and Mycoplasma infections in many clinical settings. Subsequently, identification of these organisms may be achieved only as a last resort, particularly if initial treatment with drugs that are ineffective against Mycoplasma or Ureaplasma species is unsuccessful.

Many patients came to see me, telling that they have Recurrent Yeast Infections, but in reality, there was no Yeast infection and there was Ureaplasma Infection, which once treated, patients were not facing the same symptoms they were having for the years.

The following conditions may be caused by infection with Mycoplasma Hominis and /or Ureaplasma species in various patient populations. ${ }^{3,4}$
a. Urethritis (Ureaplasma only)
b. Pyelonephritis
c. Cystitis
d. Pelvic inflammatory disease ( Mycoplasma hominis only)
e. Urinary calculi ( Ureaplasma only)
f. Endometritis or chorioamnionitis
g. Infectious arthritis
h. Surgical and nonsurgical wound infections
i. Preterm labor (Ureaplasma only)
j. Bacteremia
k. Pneumonia

\section{Meningitis}

Mycoplasma and Ureaplasma causing Infertility issue in woman and man, urethritis, female cervicitis, and pelvic inflammatory disease, arthritis.

The Ureaplasma Urealyticum and Ureaplasma Parvum are now designated as separate species. Separation of these species is not possible except via molecular techniques such as polymerase chain reaction (PCR). Ureaplasma Parvum is generally the most common species detected in various clinical specimens but Ureaplasma Urea lyticum is apparently more pathogenic and can cause infertility in women and men. 


\section{Genital herpes}

Genital herpes is a common sexually transmitted disease (STD) that any sexually active person can get. ${ }^{5}$ Most people with the virus don't have symptoms. Even without signs of the disease, herpes can still be spread to sex partners. Recovery from the Genital Herpes was quick with Negative Ions, Anion napkins. Condon cannot protect from this infection.

\section{Human papilloma virus (HPV)}

My article "Miraculous effects of Negative Ions on Cervical Dysplasia and HPV" is on the way of publication.

\section{Chlamydia}

Chlamydia is sexually transmitted disease (STD) and in the most cases there are only few symptoms, like vaginal discomfort, smelly discharge. This infection affects the infertility in men and women. Chlamydia cases Ectopic pregnancy. In pregnant women can cause miscarriage, preterm birth and there the consequences for the newborn. ${ }^{6}$

\section{Islam and modern science}

Recently converted to Islam after being atheist I discovered that Medicine is powerless in many health problems. There are some diseases caused by jinn possession, evil eye, black magic which can be treated only by Allah's words, Quran. The pain can disappear just by reciting Dua, two phrases. Incurable cancer, severe diseases can disappear by Ruqya, verses from Quran.

Many physicians, after discovering the Truth about our Universe created by Allah, were converted to Islam. Just read the story of Dr. Laurence Brown, American Ophthalmologist, who was also atheist and after Allah's Miracle, saving his daughter, converted to Islam..$^{711}$

\section{Quran is a cure for everything}

The Creator has clearly told us that the words of the Quran are a "shifa" (healing) for all and, therefore, when used with real belief in one's heart, this form of treatment can bring miraculous cure to all forms of ailments.

Allah says in the Quran, Surah Al Israa 17-82: “And We sends down of the Qur'an that which is healing and mercy for the believers). "And when I am ill, it is (God) who cures me", Quran, Surah AshShu'ara, 26-80.

\section{Unlawful sexual intercourse}

Zina is an Islamic legal term referring to unlawful sexual intercourse and can include adultery (of married parties), fornication (of unmarried parties), prostitution, bestiality, and rape. Several verses in Quran refer to unlawful sexual intercourse. Unlawful sexual intercourse, including homosexuality, is considered a major sin with specific punishment. ${ }^{12}$

Allah (subhana watallah) in Surah Al Isra, Quran says: "And do not approach unlawful sexual intercourse. Indeed, it is ever an immorality and is evil as a way." [Quran, 17: 32].13

\section{Positive and negative ions}

\section{Positive ions}

Unhealthy, man-made, environment in which we live (radiation from electronic and electrical devises, lighting, signboard, WI-FI,
Radars, video camera; air pollution; toxins like pesticides, chemical cleaners, building materials, air conditioning, unhealthy food and lifestyle) contributes to the excessive positive ions, increasing the acidity, inflammation in human body, the primary cause of low immunity and the diseases. In the body with high acidity, the bacteria, virus, cancer cells multiply quicker.

Negative ions are not present in normal numbers because the conditions that generate negative ions have been limited, overcome and/or removed as a result of human activity in the atmosphere.

\section{Negative ions (anion)}

Negative ions are abundant in the nature, the God blessing gift, put our body in alkaline and in alkaline, bacteria, virus, cancer cells can't develop; can cure even incurable cancers, diseases... Negative Ions, "Nature's Battery Chargers", are a major natural element that provides energy to human body while Medical Professionals has no knowledge or remaining skeptical. Negative Ions are known since longtime (Figure 1).

\section{Nobel Prize}
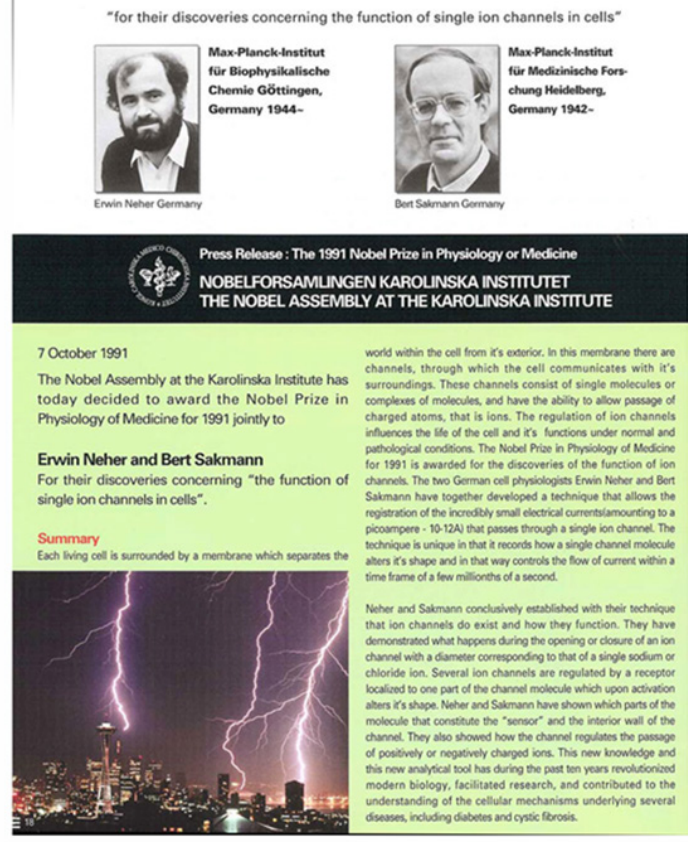

Figure I Function of single ion channels in cells.

\section{Benefits of negative ions}

I have been using Negative Ions products, mainly Anion Napkins and Energy Stone from Healthgate Company (initially Winalite) in Dubai since 2010 for all health conditions including infertility, premature menopause, infections, cervical dysplasia, pain, psoriasis, migraine, arthritis, constipation, stress, insomnia, depression with miraculous results. Negative ions are as necessary as water and air. ${ }^{14}$

Negative ions are actually oxygen atoms with extra-negativelycharged electrons, invisible molecules abundant in nature, especially around waterfalls, sea, green mountains and forests, after a storm.

They are created in nature as air molecules break apart due to sunlight, radiation, and moving air and water. The degree to which negative ions contribute to overall well-being and health is 
scientifically proven. ${ }^{14-31}$ by keeping our body alkaline, reducing inflammation, reviving all functions:

a. They neutralize free radicals, have anti-bacterial, anti-viral effects

b. They revitalize metabolism

c. They enhance immune function.

d. They purify the blood, improve blood circulation, decrease blood sugar, cholesterol, increase calcium

e. Anti-Allergic, Asthma effects,

f. They balance the autonomic nervous system, regulate the heart rate, digestion, respiratory rate, pupillary response, urination, and sexual function

g. Increasing Brain Serotonin, reducing anxiety, stress, fatigue, depression, migraine, better sleep, relaxation

h. Natural painkiller, anti-inflammatory effect

i. Improve skin conditions, against hair loss

j. Longevity, Anti-Aging, Rejuvenation (Figure 2). ${ }^{17}$

\begin{tabular}{|l|l|l|}
\hline Environment & Anion $\left(/ \mathrm{cm}^{2}\right)$ & Relation \\
\hline Forests \& waterfalls & $>10000$ & Cure disease \\
\hline Alpines \& Sea sides & $2000-10000$ & Against disease \\
\hline Parks of cities & $500-1000$ & Keep healthy needs \\
\hline Houses of cities & $40-100$ & Cause some diseases \\
\hline Air conditioning & $0-25$ & Disease can flourish \\
\hline
\end{tabular}

Figure 2 Relation of environment in anions.

\section{Other treatments boosting the immunity by alkalizing human body}

Oxygen Therapy (Otto Warburg, MD (Nobel Prize in Physiology Winner, 1931); The Gerson Therapy, Juicing; The Budwig protocol; Detoxication. All these treatments bringing us to the clean nature, God blessing gift, out of air pollution, radiation, unhealthy food and lifestyle-man-made atmosphere

\section{Autophagy (32)}

Last Messenger of the God was fasting Mondays and Thursdays and Full Moon days, so, around 9-14 fasting days per month with antidiseases, rejuvenation effects. And Dua to Allah is quicker accepted when fasting. Everything was already written in Quran which science has been discovering.

\section{Studies}

Several patients presented with chronic pelvic and vaginal discomfort, urinary tract symptoms, vaginal itching, burning. They were treated by different antibiotics without proper laboratory investigations and symptoms were persisting.

The most spectacular case was with a lady who was presenting Urinary Tract Symptoms with pain on urination and urgency, frequency, causing to urge to urinate every fifteen minutes for one year. She was looking for toilet locations limiting her activities and with impossibility to travel being attached to toilet. She tried different antibiotics by different doctors. When I checked for the most frequent infections which can cause urinary symptoms, Ureaplasma Urea lyticum and Mycoplasma Genitalium were found but they were resistant to all antibiotics proving the aggressivity of the infections and low immunity and wrong previous management. So, I suggested Anion Napkins as Medicine was powerless anyway and the same day she walked $10 \mathrm{~km}$ on the beach breathing sea air containing Negative Ions and $20 \%$ more oxygen. Two weeks later, surprisingly, Mycoplasma disappeared and Ureaplasma became positive to half of antibiotics just by Negative Ions. She felt a lot of energy using Anion napkins and she went back to her previous normal life.

I used Anion napkins from Healthgate company (previously Winalite Company in Dubai).

Negative ions $\left(6090\right.$ Anion $\left./ \mathrm{cm}^{2}\right)$ are on the green part of Anion pantilyner which should be in contact with the skin of genital area, additonal Anion can be on the plantar or bottom surface of the foot or inside of the bra or anywhere on the skin. To activate negative ions few drops of water should be on the green Anion part. It is better to change once or twice per day to have better result.

That time I didn't know about baking soda and lemon, another way of alkalizing body but in my practice, Negative Ions are superior to any other natural treatment (Figure 3). The Ureaplasma Urea lyticum and Ureaplasma Parvum infections can persist during pregnancy regardless the different antibiotics as the pregnancy is considered an immune deficiency status maintaining and worsening the preexisting infections. Few patients delivered prematurely and one had late miscarriage at four months of pregnancy. Few months after delivery these infections can leave the human body without treatment just using Anion napkins as maintaining infection condition, pregnancy, was not present anymore.

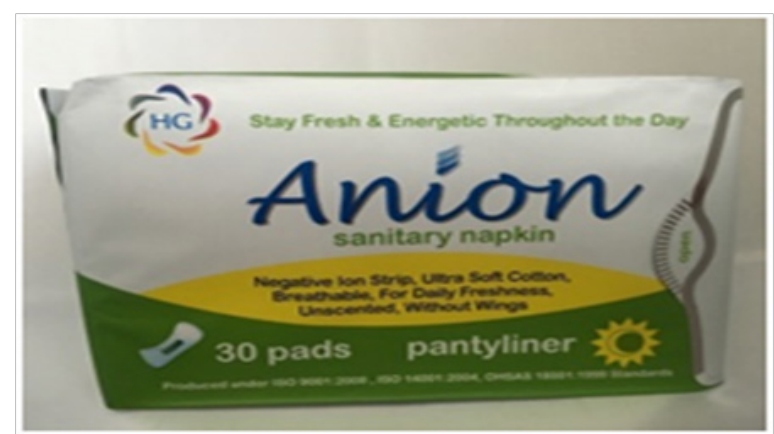

PPROTECTIONS

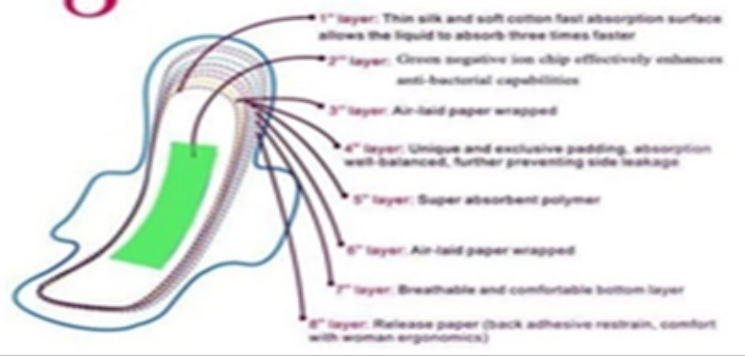

Figure 3 Anion sanitary napkins.

The ideal is the screen for the infections like Chlamydia, Ureaplasma, Mycoplasma before pregnancy to avoid dramatic consequences (late miscarriage, preterm birth). 
The Ureaplasma and Mycoplasma infections were considered longtime as sexually transmitted diseases but recently they can be found in virgin women too. I had a virgin patient who was presenting pelvic discomfort, back pain, urinary symptoms and received by different doctors the different treatments without laboratory tests. When I checked for Ureaplasma and Mycoplasma infections, Ureaplasma came back positive. All symptoms, she was having for one year, disappeared after adapted treatment and Anion napkins.

\section{Conclusion}

Some of the urogenital infections are sexually transmitted and the transmission is increasing with multiples partners.

\section{Quran says}

Do not follow desires if you want to go to Paradise as unlawful sexual life is a major sin with a specific punishment in hereafter. Abu Hurairah (May Allah is pleased with him) reported ${ }^{13}$ The Messenger of Allah said, "He whom Allah saves from the evil of that which is between his jaws and the evil of that which is between his legs will enter Jannah".

The Urogenital Infections can be treated successful by healing power of nature, the God blessing gift. In the clean nature the high concentration of negative ions not only maintaining healthy needs but can cure incurable cancer. It is all about alkalizing human body as in alkaline body the virus, bacteria, cancer cells cannot survive.

Man-made atmosphere (radiation, air pollution, unhealthy food and lifestyle) with high concentration of positive ions put your body in acidity, inflammation, the main cause of almost all diseases.

The Negative Ions (Anion) products and from the nature will keep your healthy needs, but should be from proven company.

\section{In the Saheeh Hadith}

For every disease there is a medicine, and if that medicine is applied to the disease, he will recover by Allah's Leave. Allah has not sent down any disease but He has also sent down the cure; the one who knows it, knows it and the one who does not know it, does not know it.

Doing many good deeds, we may please Allah and ask for the cure from the diseases and for Paradise. The Nature with healing power is a God blessing gift and we should preserve the Nature intact for our future generation and for our health.

\section{Acknowledgements}

None.

\section{Conflicts of interest}

None.

\section{References}

1. Vaginal Candidiasis. Centres for disease control and prevention (CDC), USA.

2. Rita Rubin Are Feminine Hygiene Products safe? Web MD. 2015

3. Ken B Waites Ureaplasma Infection Clinical Presentation. Drugs \& diseases, Medscape. 2017

4. Ken B Waites Ureaplasma Infection. Drugs \& diseases, Medscape. 2017

5. Genital Herpes-CDC Fact Sheet.
6. Angelova M, Kovachev E, Tsankova V, et al. Role and Importance of Chlamydia Trachomatis in Pregnant Patients. Open Access Maced J Med Sci. 2016;4(3):410-412.

7. How I came to Islam-Dr Laurence Brown | Interfaith Issues-Episode 3

8. Prof. Keith Moore converts to Islam after finding scientific facts about embryology in the Quran.

9. https://en.wikipedia.org/wiki/Maurice_Bucaille

10. Dr. Zakir Naik, Quran \& Modern Science.

11. Ahmed Deedat, Quran is a Miracle of Miracles.

12. The Book of the Prohibited actions.

13. Dr. Zakir Naik, Zina (unlawful sexual intercourse) and its punishment in Islam.

14. Denise Mann Negative Ions create positive vibes. Web MD. 2002

15. The Ion Miracle The benefits of negative ions on physical and mental well-being by Jean-Yves Cote. Quebec Network Ltd., 6721 East Beaubien, Montreal, Quebec H1M 2B2, Canada.

16. Howard PJ $x$ The Owner's Manual for the Brain: Everyday Applications from Mind Brain Research. Leornian Press, Austin, pp. 399. 2002.

17. Dr. Sang Lo Byung Sa Science: Power of Negative Ions-Restorative Medicine of Nature. 2013

18. Flory R, Ametepe J, Bowers B A randomized, placebo-controlled trial of bright light and high-density negative air ions for treatment of Seasonal Affective Disorder. Psychiatry Res. 2010;177(1-2):101-108.

19. Sulman FG) Migraine and headache due to weather and allied causes and its specific treatment. Ups J Med Sci Supp. 1980;1 31: 41-4.

20. Udermann $H$, Fischer $G$ Studies on the influence of positive or negative small ions on the catechol amine content in the brain of the mouse following short time or prolonged exposure. Zentralbl Bakteriol Mikrobiol Hyg.1982; [B] 176(1):72-78.

21. Goldstein N, Arshavskaya TV Is atmospheric superoxide vitally necessary? Accelerated death of animals in a quasi-neutral electric atmosphere. Z Naturforsch C. 1997;52(5-6):396-404.

22. Livanova LM, Levshina IP, Nozdracheva LV, et al. The protective action of negative air ions in acute stress in rats with different typological behavioral characteristics. Neurosci Behav Physiol. 1999;29(4):393395.

23. Reilly T, Stevenson IC An investigation of the effects of negative air ions on responses to submaximal exercise at different times of day. J Hum Ergol (Tokyo). 1993;22(1):1-9.

24. Kosenko EA, Kaminsky Yu G, Stavrovskaya IG, Sirota TV, Kondrashova MN The stimulatory effect of negative air ions and hydrogen peroxide on the activity of superoxide dismutase. FEBS Lett. 1997;10(2-3):309312 .

25. Research review: Health benefits of negative ions.

26. http://www.biomathealthsolutions.com/negative-ions.htm

27. Sang Y Whang Reverse Aging. (2nd edn), Division of Sang Labs Inc, Miami, USA, p. 24.1990

28. Bob McCauley The Miraculous Properties of Ionized Water-The Definitive Guide to the World's Healthiest Substance. 2006

29. Dress for Health- Negative Ions.

30. Ionized Alkaline Water around the World: Japan.

31. Medical Case Studies Alkaline Water.

32. Mizushima N Noboru Mizushima: All about autophagy. Interview by Caitlin Sedwick. J Cell Biol. 2010; 190(6):946-947. 